\title{
XXXVIII. Description of an inclosed grindstone, intended to prevent prejudicial effects to the persons employed in pointing needles
}

\section{Mr. Thomas Wood}

To cite this article: Mr. Thomas Wood (1812) XXXVIII. Description of an inclosed grindstone, intended to prevent prejudicial effects to the persons employed in pointing needles, Philosophical Magazine Series 1, 39:168, 262-263, DOI: 10.1080/14786441208638123

To link to this article: http://dx.doi.org/10.1080/14786441208638123

电 Published online: 27 Jul 2009.

Submit your article to this journal $\pi$

Џll Article views: 2

View related articles 
Upper Ashop, in Hope Woodlands, NW (Combs-Tor), very large; (Dine-Sitch Tor): and $\mathbf{N}$ (Collet Hay).

Wensley, near Winster, N.

Willersley, in Matlock, NE.

Wirksworth, NW (Bole-Hill).

Woodhead, Cheshire, SE.

Woodseats-Hall, in Barlow, $\frac{1}{2} m$. SW, in 2nd Coal Shale.

All the above Slips, except five, which are mentioned, and numerous other smaller ones, are occasioned by the Limestone Shale; sometimes the sunk pieces contain part of the 1 st Grit Rock on the Shale, or large pieces of shale Grit, or shale Limestone, perhaps, in their masses.

As in the judgement of some I shall be thought, probably, to have said too much already on the form and surface of the County, I shall now close this Section by mentioning, that Derbyshire contains about 972 square English miles, or 622,080 statute acres $\%$.

XXXVIII. Description of an inclosed Grindstone, intended to prevent prejudicial Effects to the Persons employed in pointing Needles. By Mr. Thomas Wood $\uparrow$.

Sra, I herewith submit to the inspection of the Society instituted for the Encouragement of Arts, \&c. a model of an inclosed grindstone, intended to prevent prejudicial effects to the persons employed in pointing needles.

This grindstone is inclosed in a case of word or metal, and hath a hood wherein a square of glass is iuserted, designed to admit light on the articles under operation.

The particular advantages attending a grindstone suspended in this manner, with a hood and a damp cloth, are, that the stream or current of air, formed by the motion of the stone on its axis, is confined by the case under the hood of

* Which is the result of a careful sealeing of my large Map. In the Original Report, Mr. Thomas Browu stated the quantity at 720,640 acres; the Parliamentary Returns of the Poor's Rates, as stated by Mr. Thomas Puole, make Derbyshire contain 689,280 acres, which last, considering that many of the Parish quantities must have been stated by estimation, agtees sufficiently near with mine above. About the year 1756, when Benjamin Martin published his Natural History of England, this County was stated to contain only 540,800 acres; but a Dictionary of Arts and Sciences, now pubiishing in London, magnfies its dimensions to 1,600.000 acres! See other particulars of the acres in this County, in Sections IV. and VI. of this Chapter.

+ From Trunsalisons of the Socteiy for the Encotragement of Arts, ManufucLures, and Commerce, for 1811 . The silver medal of the Society was voted to Mr. Wood for this invention, and a model of the Apparatus is preserved in t'ie Suciety's Repository.

which 
which it enters, and carries with it the fine particles of steel and sand, which it deposits on the lower part of the inside of the wet cloth, which forms the connection between the sides of the case, by these means rendering the operation of pointing needles less pernicious to the health of the operator. The stone may be worked by hand, by water, or machinery.

I am, sir, most respectfully,
Great Berkhampstead, Herts, January 25, 1811. THOMAs WoOD.

To C. Taylor, M.D. Sec.

Description of the Engraving of Mr. THomas Wood's Improvement in the Grindstones for Pointing Needles. Plate VI. fig. 1.

The grindstone $\mathbf{A}$ is inclosed in a box or case, formed of two circles of wood, one marked B, and another on the opposite side, which cannot be seen in this view; $a \boldsymbol{a}$ are two thin iron plates placed so near to the stone, as to be as close to it as possible without touching it ; two other plates $b$, support a pane of glass at $c$, which at the same time that it prevents the dust from being thrown over the stone into the air, admits light to that part of the stone where the needles are applied; the remaining space between the edges of the two circular boards B, is filled up by a coarse cloth $D$, which encompasses about $\frac{3}{4}$ of the edge of the stone, and is then hooked up to the iron plates $a$, by means of two bent pieces of plate iron, to which the clotb is sewed, one of which is seen at $d$; and these are hooked upon other bent pieces, which form part of the plate $a a$; the cloth is wetted when put on, and will then catch the dust which is" produced by the grinding, and when it has accumulated much, by unhooking the cloth it may be shook out, and the cloth being wetted is hooked on again; as the stone wears down the piece of plate iron $e$, situated in a groove formed by the edges of the plate $a$, is slided forwards to follow up the reduced edge of the stone, and other plates are put into the groove after $e$, when they are required; the case $B$ is supported by a cross-bar of the frame in which the stone revolves, and which may be made in this or in any other form; the stone is turned in the usual manner of grindingmills for needles, by a strap passing round a rigger, fixed on the end of its spindle; but this cannot be seen in this view, it being hidden behind the stone. 
Mr? Woods Enelosed Grindestome, for Porinting Needles.

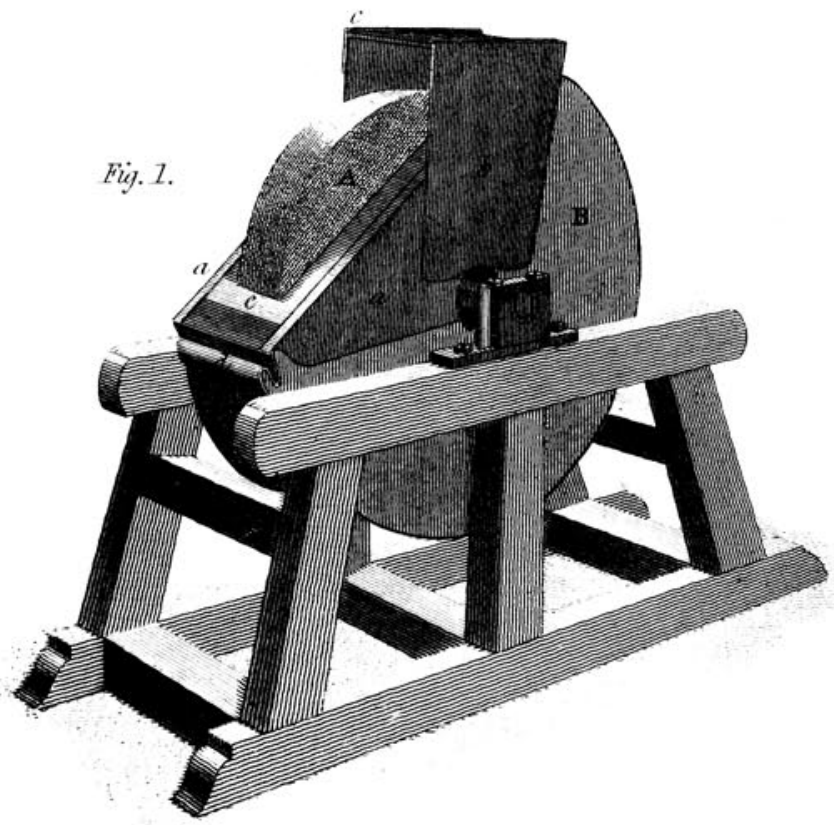

Phil.Mag. Foi.XXXIX.Pl.o.

Mr. Webstess Method of enreving

off iteam fivm Boilers.

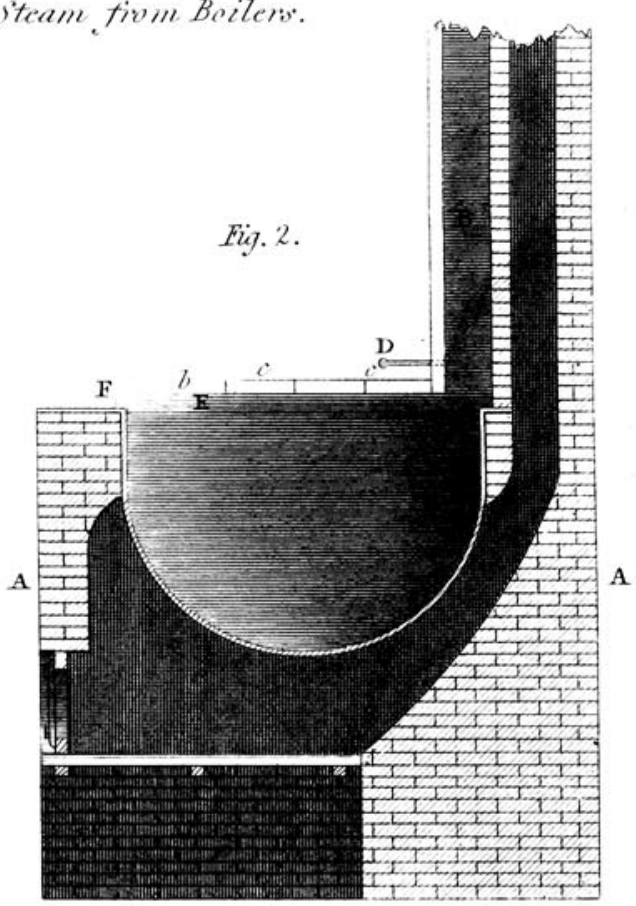

